\title{
75 Years After the Social Pact: A Brief History of the Socio-Technical Evolution of Social Security in Belgium ${ }^{1}$
}

\author{
Raphael Van Lerberge \\ Free University of Brussels (VUB)
}

\begin{abstract}
Belgium was one of the first countries in Western Europe to celebrate at the end of 2019 the 75th anniversary of a generally compulsory social security system. But this was done with a certain reluctance as if the main actors, the administrators of the system, were alienated from the original principles. In this contribution we examine how this social security evolved by also taking socio-technical factors into account. To establish that the current system has indeed moved a long way from the basic principle of 'solidarity', and rather has the characteristics of a large technical system in which individual needs can be detected and an individual compensation system can be developed. Provided that the insured assumes responsibility and actively participates in the welfare society. This is the paradigm of the Third Way, which is complementary to the technical foundation of the current network system. The role of administrators (intermediaries as trade unions, health insurance funds, etc.) is limited in this respect, hence the lukewarm revelry in the celebration of a system in which they hardly recognize themselves.
\end{abstract}

Keywords: office technology, social security, information technology, social pact, Goldschmidt, sociotechnical system, Troclet, IT

\section{INTRODUCTION}

The 75th anniversary of the social security system has (so far) only given rise to a limited number of retrospectives by academics. Among these are interesting essays by specialists such as Dirk Luyten ${ }^{2}$ and Koen Vleminck ${ }^{3}$. In a concise contribution, Bea Cantillon mainly describes the evolution of the function of the system in the social landscape. ${ }^{4}$ She highlights an intensive interaction between the system and the social context and focuses on the new challenges. This contribution also has few historiographical ambitions and certainly does not aim at a critical evaluation of the historical development of the system over the last 75 years.

At the end of 2019, historical retrospection was scattered among the institutions themselves, with the exception of the National Office of Social Security Office (NOSS), which held an academic session in the House of Representatives on 20 December 2019 during which reticence about the past was striking. Instead, the focus was on modern social security, with an eye to the future; on this occasion the NOSS also launched a website ${ }^{5}$, but with limited content in terms of historical reflection.

It was as if we were looking away from the historical momentum that took place in 1944. Apparently, there was no need to critically examine the evolution of the 75 years and learn from it in order to approach the current challenges from a historical perspective. 
The main objective of this contribution is therefore to analyse this evolution critically and to establish a link with the current functioning. We adopt an approach based on both societal and technical components. This approach differs from classical historical approaches, which give full attention to the socio-political dynamics underlying the evolution of the system. However, socio-technical dynamics also play a decisive role. Most of the time, however, they remain hidden in the technical 'black box' that the system has become. We would like to open up this 'black box' a little.

\section{THE HISTORY AND MOMENTUM OF THE SOCIAL PACT (....1948)}

Already in the 19th century, the first steps were taken to insure citizens against the risks of economic inactivity and thus loss of income. The first pension-related measures date back to 1849 . However, social demands were formulated mainly at the instigation of social movements which took shape within their own organisations, offering assistance in the event of sickness, unemployment, pensions and family allowances. In its own way, the employers also participated in these social developments (especially in the area of family allowances). The authorities were supportive but remained rather passive. In the period before the Second World War, health insurance funds, pension funds, family allowance funds, trade unions, etc. were active and granted allowances to their members. This was a period in which institutional pluralism flourished: dozens of private, often politically colourful organisations each set up their own social insurance system. In the $1920 \mathrm{~s}$, the first ideas emerged to generalize and make these social insurance systems compulsory. This was done for pensions and family allowances. The culmination was the legal obligation in 1937 to also insure the self-employed for family allowances. This was the first sector of social security to become compulsory in general for the entire Belgian population, i.e. for both workers and the liberal professions.

During this decade of the 1930s, when the economic crisis hit hard and the need for general compulsory insurance became apparent, new commissions were set up to look into the obligation of general social insurance. However, the debates became bogged down in discussions on both the content and the technical and structural aspects, where each group concerned had an ideological argument against the proposals of another group. One of the contentious points was the role of the state, balanced against the activity of private institutions. The debate then pitted the proponents of a system, organised and implemented by the public authorities, against the proponents of institutional pluralism.

The occupation of land and the associated discussion about which organisation could remain active in a given sector was also a permanent point of discussion. This debate was linked to the compartmentalisation of social security. Trade unions certainly wanted to remain active in unemployment, but some had objections to purely administrative enforcement. Employers defended their services in the area of family allowances, but the exclusive management of this area by employers was in turn contested by the unions. In the health insurance sector, a variety of organisations were active and there was a high level of clientelism. Proposals to unify the sector and have it run by a national institution were not welcomed with open arms by, for example, the Christian mutual societies, which were very attached to the philosophical link with insured members. On the employers' side, there was support for an enterprise-based organization, which was not acceptable to politically coloured organisations. In terms of pensions, the basic debate was about the principle of pension building: a capitalisation system, in which the individual was responsible for building a pension himself and alone, possibly with the support of employers and/or public authorities, or a pay-as-you-go system, in which a collective system gave the individual a pension guarantee.

There was also no agreement on the operating principle of contribution payment. Did the public authorities have to bear all the burdens through taxation, or was the individual solely responsible? Was the employer co-responsible for all risks and how would the contribution be collected? Christian mutual societies, in particular, were strong advocates of individual collection of membership fees.

All discussions on both substantive and technical provisions were rooted in the ideological compartmentalisation of the time. There was a great deal of resistance, which was very tenacious. This was still the case after the war, when a new system was established. 
There were some indications that in some areas a consensus could be reached. In December 1936, the Catholic senator Léon Coenen pleaded in the Senate for a "one-stop shop" that would take care of the central collection and distribution of contributions. ${ }^{6}$ Similar ideas about central collection, payroll deduction and thus the employer and employee contribution were also formulated in discussions within the framework of the Royal Unemployment Commissariat (1936) under the leadership of Henri Fuss. ${ }^{7}$ However, these proposals could not be implemented before the war. The discussions led to the formation of a group of socio-technicians, who approached the organisation of a social security system not only from an ideological point of view, but also from a technocratic, technico-administrative point of view.

Another turning point was the legal obligation in 1937 to also insure the self-employed for family allowances. The principle of a compulsory social security system for the whole population was thus realized. In addition, the implementation of this sector was entrusted to private funds, but it was also supported by a mechanical administrative system, which was innovative at the time. In this achievement, the technical component was clearly put forward. The creation of the Society For Mecanographie (SFM) in 1939 marked a turning point. This can be described as an "infrasystem": an organisation with mainly a technical, executive function and equipped - what was then considered the most modern technology - with a punch card system and a mechanical addressing system.

A new dynamic arose during World War II. There was the rapid growth in maturity of the family allowances sector, which became widespread and covered workers as well as the self-employed and which, moreover, succeeded in developing technical knowledge in the functioning of the Society For Mecanography. This knowledge could be used in the development of a comprehensive social security system. On the other hand, in different circles original solutions were devised to overcome pre-war disputes. Both in London and in occupied Belgium, post-war social security plans were drawn up. But it was above all the group of socio-technicians, united in what is called the Clandestine Committee, which began to rethink the pre-war plans and which finally, freed from the socio-political obstacles, proposed to conclude a agreement between employers and workers, in order to create post-war socio-economic conditions favorable to the whole society. The initiative became the foundation of the welfare state: work and employment, hence production, would ensure prosperity, and economic growth could be guaranteed by involving citizens in this prosperity. 


\section{FIGURE 1 \\ OUTLINE OF A DISCUSSION TEXT}

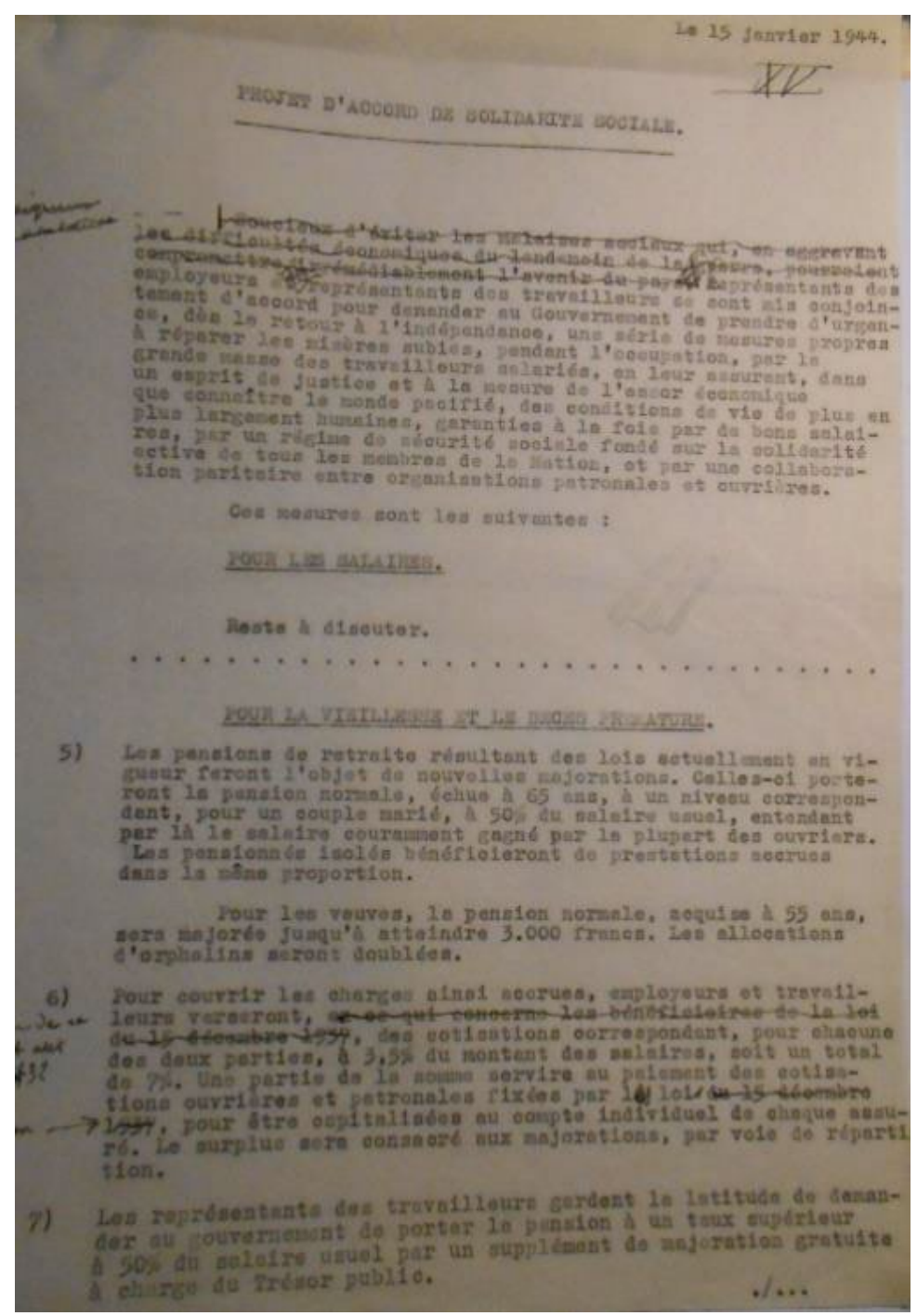

Outline of a discussion text that later became the basic text of the Social Pact. The notes are by Léon Delsinne, one of the members of the Clandestine Committee.

Source: Delsinne documents, Cegesoma/ARA.

From this point of view, a system was created under which workers were entitled to a pension, an unemployment benefit, a sickness benefit (long-term or not), care reimbursement, family allowances and holiday pay. The aim was also to extend this insurance against social risks to all population groups, such as the self-employed. These proposals were included in the "Draft convention of social solidarity" (April 1944), later called the Social Pact, which was translated into the legislative decree of 28 December 1944. As a result, Belgium became one of the first Western countries to offer workers a comprehensive social insurance system with a number of essential features that strongly determined the future. For example, the financing was borne by workers and employers, on the basis of a deduction from wages: social contributions. These were collected via employers, who had to pay them to a central agency, the National Office of Social Security (NOSS). The NOSS was in turn responsible for receiving the funds and making them available to parastatal institutions. These new institutional nodes then paid to the organisations, which actually distributed the allowances to the insured. These were the dozens of pre-war social institutions that 
existed before the war, such as holiday funds, mutual societies, pension funds and so on. Thus, all insured persons had identical rights, irrespective of their membership of a paying institution.

A new dual structure was thus created: a series of (parastatal) institutions that would distribute the money and control its use. These institutions were run by representatives of employees and employers, as well as representatives of the minister. This is known as parity-based management. On the other hand, the hundreds of executive organisations were obliged to submit to the central provisions and accept control by parastatal institutions.

In summary, the Social Pact, and later the Decree Law, laid the basis for a social insurance system that insured the worker against the risks of loss of income due to ageing (pension), sickness, unemployment. The system provided support for the family (family allowances) and gave the right to holidays (holiday pay). The technical operating principle implied that the funds, coming from the salary, were collected centrally and then distributed. Existing institutions ensured payment to insured persons and checked whether they were entitled to benefits. The scheme itself was managed by the social partners, under the supervision of the public authorities.

\section{FIGURE 2}

\section{THE SOCIAL PACT PROJECT}

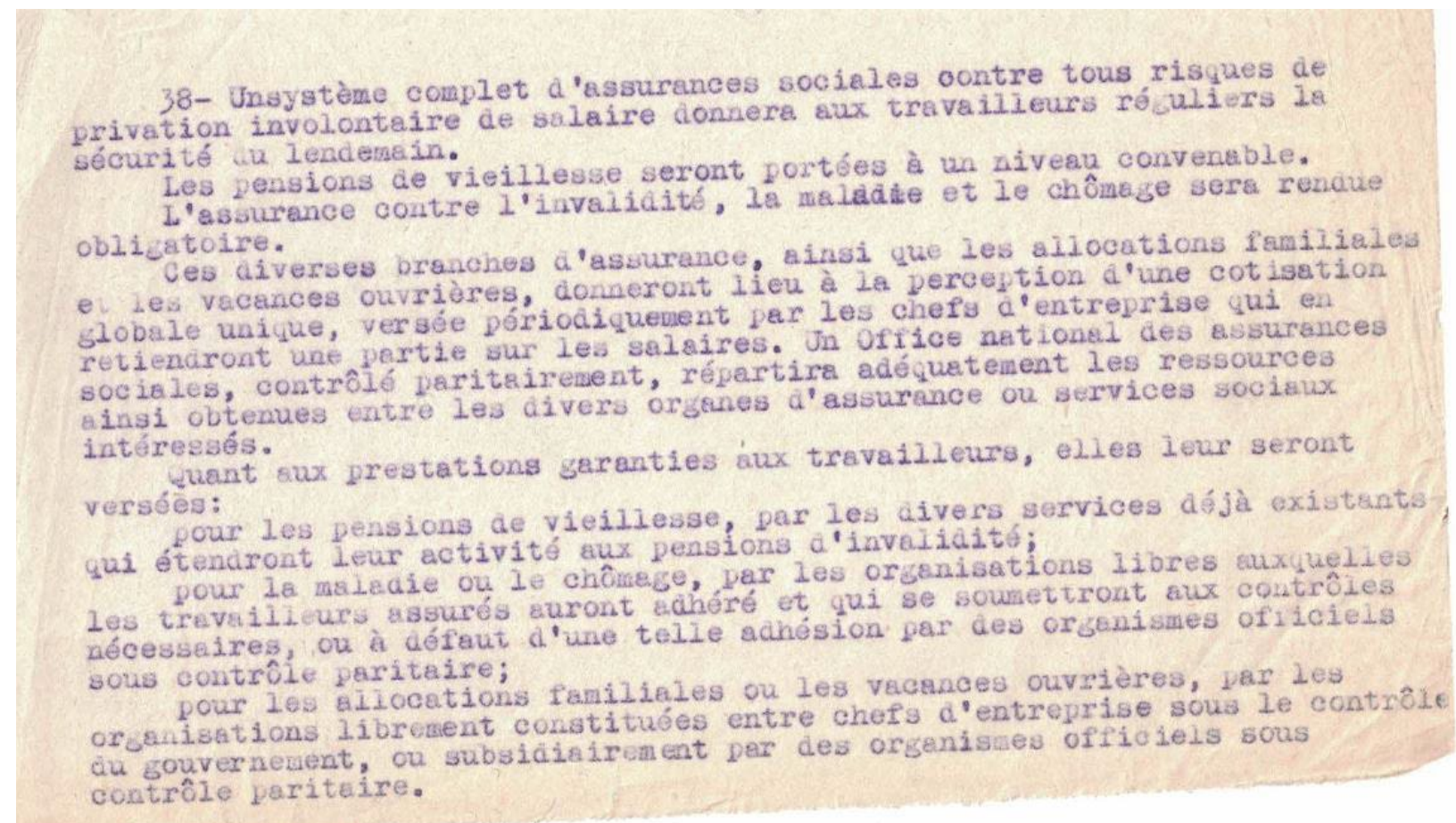

Extract from the draft (probably 1943) of the Social Pact. This paragraph describes the basic principles of the postwar social security system. It concerns the establishment of a system of social insurance for workers with coverage against the risks of loss of wages in old age, family allowances, holidays, sickness and invalidity. The unitary contribution paid by workers and employers is deducted from wages and collected centrally by a national service. Existing institutions, albeit controlled by the public authorities, will be used to implement the system.

Source: P. Goldschmidt archives, various documents.

This system is an example of what was later called 'institutional bricolage', which means that for pragmatic reasons, existing elements are used to build a new construction. ${ }^{8}$ In the case of post-war social security, this can be taken literally. Especially for the practical implementation of social security, the prewar structures, in this case the dozens of private organisations, were used. 
The realisation of the concept of central perception posed further challenges for the initiators. From the outset it was decided to set up two new institutions: the NOSS as general distributor and, for the health insurance sector, the creation of a National Fund for Health and Disability Insurance (NFHDI). But the creation and functioning of these institutions was not easy. Both were faced with the same post-war problems, such as the difficult search for suitable offices, whose availability was limited due to war damage. Finding staff was an arduous task: the best staff had been requisitioned by Allied troops and a legally enforceable work statute was missing. Fulfilling managerial functions was not easy either, due to the lack of specific skills. Practical implementation was hampered by a lack of paper and office machines.

It was therefore a do-it-yourself in the most literal sense and, for example, as the new general administrator of the NOSS, Goldschmidt was able to consider himself fortunate in 1945 to have an office and a secretary from the National Compensation Fund for Family Allowances. The NFHDI was confronted with a similar problem, but one could rely on the existing functioning of the mutual societies, which were not particularly motivated to boost a central institution that would control them. Hence the decision within the NFHDI administration not to equip the institution with office technology such as a punch card system. The challenge here was above all to standardise the implementation of the legislation and then to enforce it uniformly across the very diverse and compartmentalised landscape of hundreds of private organisations.

In other sectors, too, existing structures could be relied on for the distribution function. In the holiday allowance sector, the central players were initially the Caisse Générale d'Epargne et de Rentes (CGER) and the holiday funds. In accordance with the spirit of institutional bricolage, these were confirmed in their function by the decree law of January 1946 and the creation of a National Holiday Fund (CNVA). However, this creation proved to be a manifest error, as a parliamentary enquiry in November 1946 revealed that it was precisely these players who had failed in recent months. Some holiday funds had applied "nebulous" practices during the war and the CGER had considerably neglected the sector during and immediately after the war. The reorganization of the CNVA (decree-law of 18 February 1947) restored order to a sector which had come under the social security system mainly for financial reasons.

In the area of family allowances, both for workers and the self-employed, it was initially possible to build on existing structures that had emerged relatively intact from the war, such as the National Mutual Fund (self-employed) and the National Compensation Fund (workers). They functioned well, also because they used the Society for Mecanography. Both funds were well affected by the post-war clean-up, but this had little impact on the concrete implementation of the family allowance system, which had also been entrusted to private organisations. It is therefore remarkable that Minister, Troclet set up a National Office for the Coordination of Family Allowances in 1947 (10 January 1947), with a coordinating, distributing and monitoring function in this sector. In addition, the National Office for the Coordination of Family Allowances was also entrusted with a significant executive function, namely the payment of family allowances to non-affiliated workers and self-employed persons. It was an institution that functioned by analogy with other parastatals and in this respect, it completed the picture of a set of institutions that slipped between policy-making and implementation. But this institution worked - especially at the beginning - as a model of an autonomous institution, with self-management, an operational structure of centralised mechanical services, combined with decentralised service provision, using the network of "Maisons du Travail"; with a personnel policy adapted to the well-being of the workers, for example by offering holiday packages and organising paramedical care; with a specific office policy; with a content input by making proposals on the organisation of social security. However, the National Child Benefit Coordination Office was also swept away by the swaying post-war policy: once Minister Troclet was replaced by an opposing Catholic minister, his wings were clipped, marking the end of this remarkable administrative experience.

In the pensions sector, the historical background weighed even more heavily. The Clandestine Committee did not at all want to touch the pre-war execution structure, which was entirely dominated by the CGER. The CGER managed not only the funds but also the individual files and had identified itself with the capitalisation system. Although doubts had been expressed about the contribution system (with the help of stamps and pension cards) and the operating principle itself, where there had already been calls for a pay-as-you-go system, this was still very premature in the post-war years. 
The implementation of the new system was therefore a long search for stability, where maximum use was made of existing structures. Moreover, in 1944 it was impossible to predict whether the project would be financially successful, since it was based on pre-war data, which it was not at all clear whether they were still relevant in the wartime circumstances.

\section{FIGURE 3 \\ OUTLINE OF THE SOCIAL SECURITY SYSTEM FOR WORKERS, 1949}

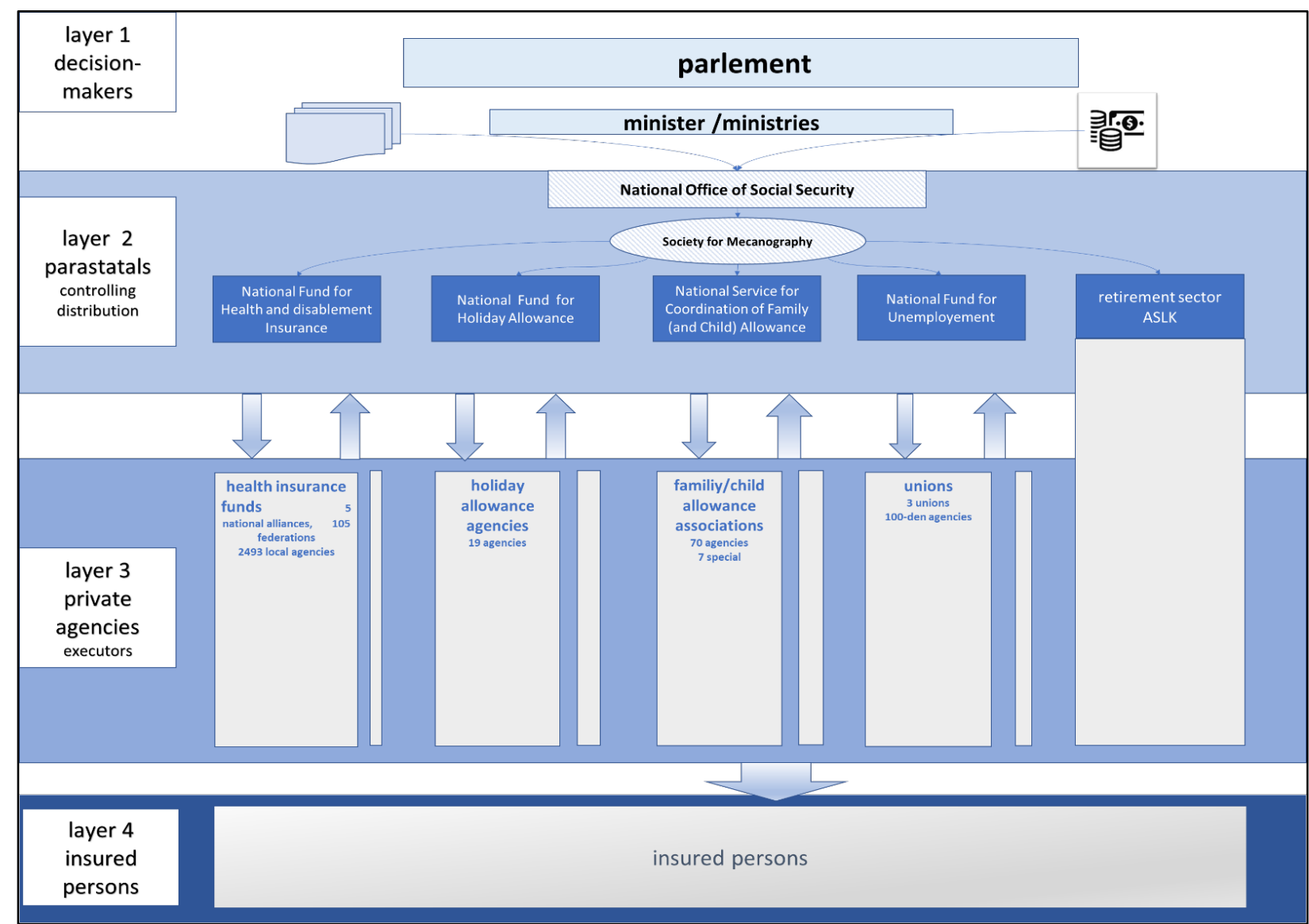

In 1949, social security for workers was a patchwork of parastatal institutions and hundreds of private organisations. It was the product of the "institutional tinkering" carried out by the Committee of Workers and Employers (the Clandestine Committee) during the Second World War and included in the Social Pact of 1944. Institutional pluralism and parity-managed parastatals were characteristic of the Belgian social security system.

Source: This is an adapted version of the scheme published in Vanthemsche, Guy, De beginjaren van ..., p. 74, with an addition of the Society for Mecanographie

To the relief of the political authorities, who feared social unrest after the liberation in 1944, the system worked well from the outset, not least because the NOSS had adopted the successful system of the family allowance punch card (of the Society For Mécanography) and introduced a number of mechanographic methods. Resources accumulated easily and social acceptance was high. In this respect, the social security system responded to a primary social and political need: to bring serenity to the population, so that reconstruction could be carried out in serene conditions. The first post-war government continued to work on this impetus and used the system within the framework of the strict wage and price policy applied until 1948. The social partners, representing both employers and workers, rallied behind this policy. At a series of national labour conferences held in 1947 and 1948, they decided to improve certain compensation 
measures, such as the introduction of double holiday pay as an alternative to a wage increase, which could lead to higher prices and thus undermine the competitiveness of enterprises.

\section{FIGURE 4 \\ TECHNICAL BRIEFING ON THE ORGANISATION OF THE NOSS}

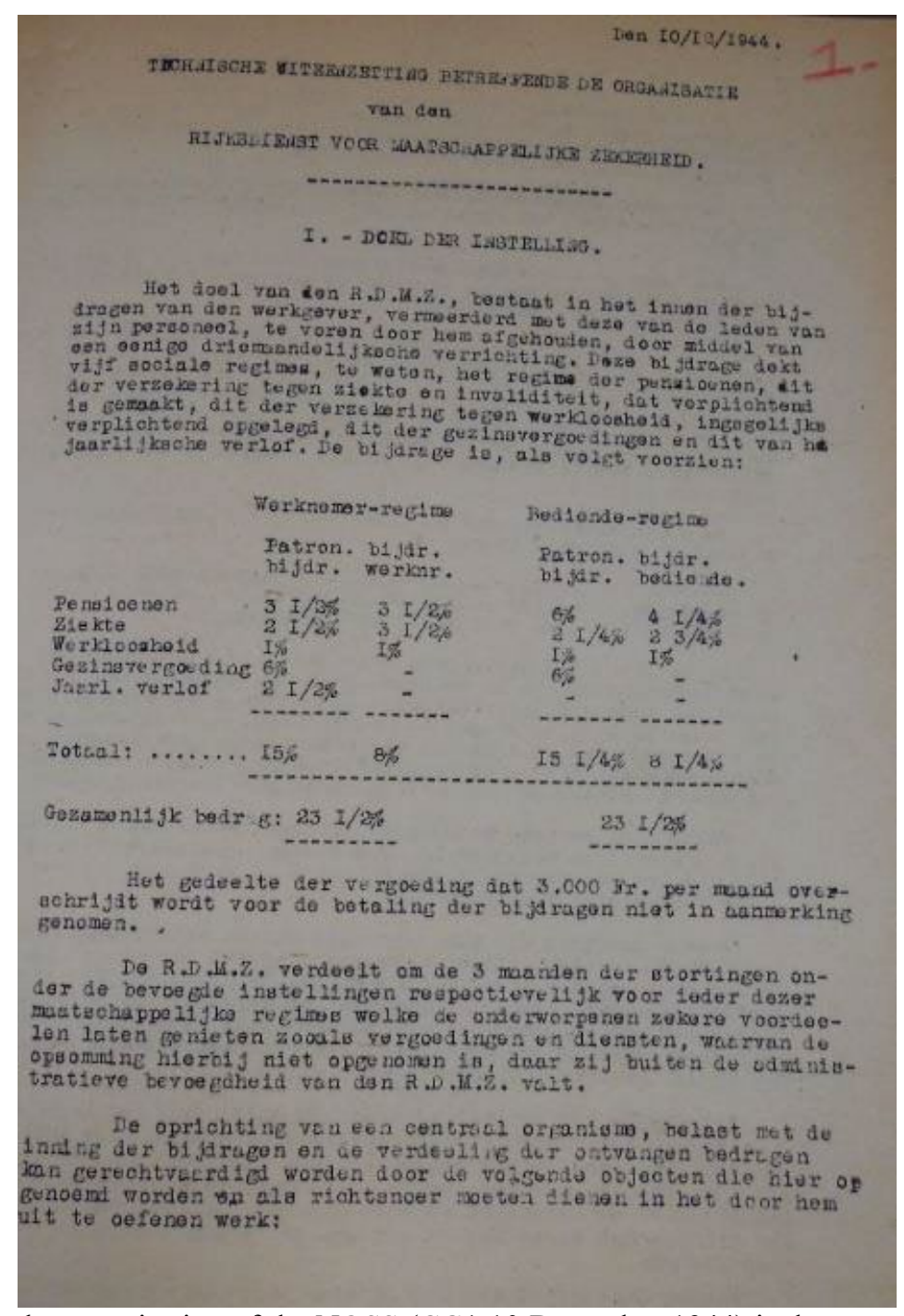

The technical paper on the organisation of the NOSS (CG1 10 December 1944) is the text on which the subsequent functioning of the institution and the central perception was based. The document is one of the cornerstones of the social security system. It contains, among other things, technical descriptions, but also a multitude of moral values on which the system was to be based, at least according to the author P. Goldschmidt. Some of these principles still apply 75 years later.

Source: NOSS archives.

However, the awareness that the system was provisional in nature and needed to be better supported remained intact. Shortly after the start in 1945, the commissions went to work to examine certain parts, such as pensions and insurance for the self-employed. At the end of 1947, beginning of 1948 it became increasingly clear that there was a fundamental error in the financial system, especially as the health insurance sector started to run large deficits. This became a recurring phenomenon: health insurance became 
the major consumer of the system. But the holiday allowance sector was also initially experiencing structural problems, and the maintenance of the capital-based pension system was also problematic.

\section{THE SEARCH FOR STABILITY (1949-1959)}

As early as 1947, the effective search for correction of the system began. Numerous attempts were made, ranging from the creation of a High Council of Social Security to the appointment of state commissioners, and partial solutions were found by the various ministers. But no proposal or measure was sufficiently sustainable, especially as these measures were part of the political and ideological rivalry between the two main political opponents. It was the socialist fractions that preferred an extension of the competences of national institutions. Such a policy was led by L.-E. Troclet, who was labelled a 'statist', but who was above all in favour of greater autonomy for the umbrella institutions under parity management, and therefore certainly not in favour of an extension of the power of the state. ${ }^{9}$ On the opposite side were the Catholic ministers, who defended institutional pluralism and tried to promote or protect implementation by private organisations. It was this oscillation that marked the 1950s: one minister would cancel the measures of his predecessor and take new measures, which were in turn cancelled. With the exception however remarkable - of the Pension Act, passed by Minister Vanden Daele in 1953, which was immediately cancelled by Troclet, who issued a new law in 1955, barely different from the first one. Historians have focused on the political controversy surrounding this law, but at the base there was a consensus on the establishment of a pension system based on a pay-as-you-go rather than a funded system. This was one of the first indications that it was still possible to reach a consensus - even if unexpressed across party boundaries. Another, less well-known example of possible consensus occurred on 23 March 1953 with the conclusion of a "national solidarity pact" between the various mutual societies for the payment of the deficit of certain national unions by the intervention of other national unions in proportion to the reserves of the latter registered on 31 December $1952 .{ }^{10}$ This pact, which not only fell between the folds of history, but was also not widely publicised at the time, was a further indication of the fact that oppositions were surmountable in the visibly highly polarised world of social security at the time.

FIGURE 5

\section{THE CONTRIBUTION VOUCHER}
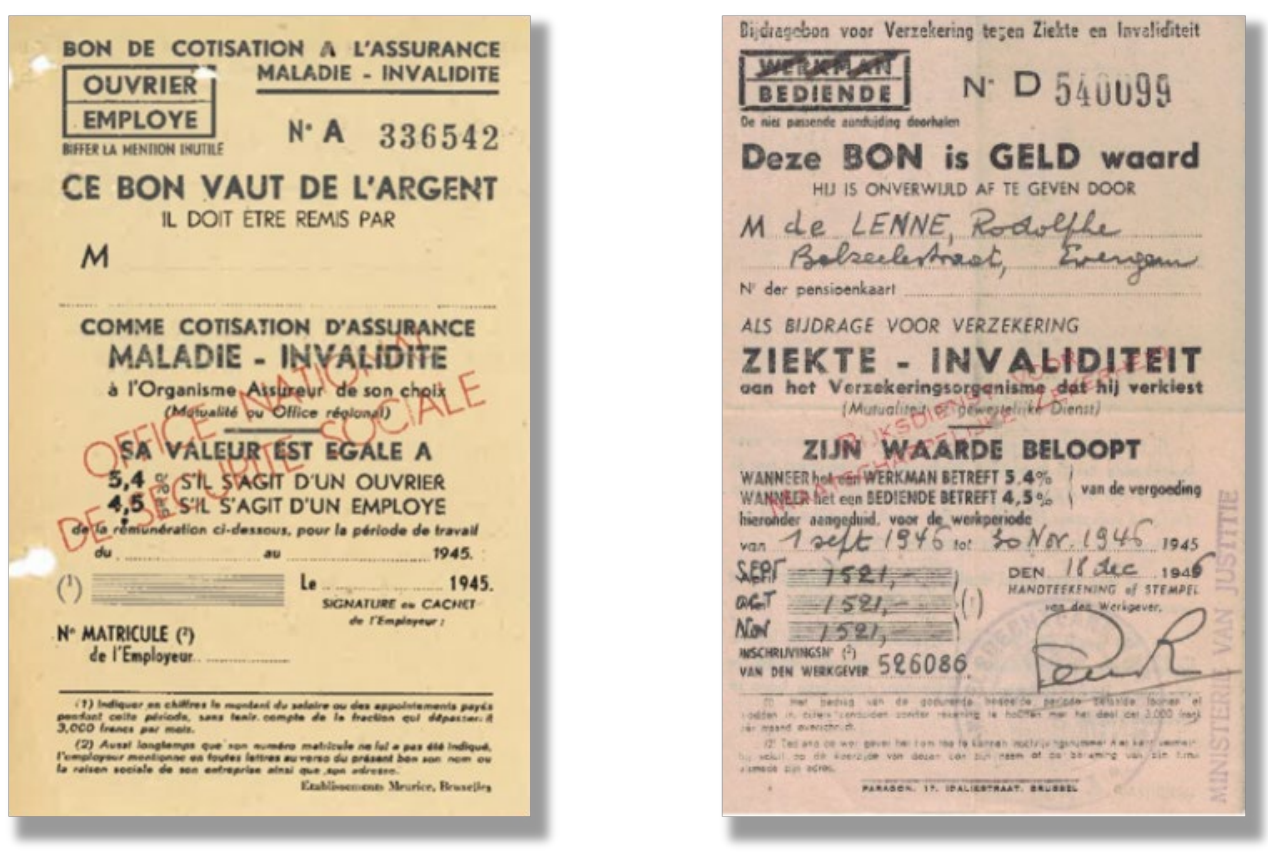
The contribution voucher was one of the many Administrative Technical Artifacts (ATA) created after the war. It was not a sinecure in itself because in 1945 there was an acute shortage of office paper machines. Such forms were a form of "frozen" reality. Filling in the data was described in instructions that had to be designed and distributed. In addition, it took months for these ATAs to reach a certain stability, both in form and content. As can be seen from the above versions, the voucher on the left is the original and the one on the right is the one that was in force a few months later. We note that the voucher on the right had already evolved in terms of form and content. This type of ATA also includes various functions, underlying procedures, approvals, etc. so that each modification caused a cascade of secondary problems. The initial period of social security was therefore a period of intense learning, an example of "social learning".

Moreover, in the 1950s, the system was characterised by growing deficits, particularly in health insurance, which were covered by a system of public interventions and loans from other sectors, especially that of annual holidays.

However, despite the financial difficulties, the proper functioning of the system itself was just as characteristic, though less discussed. The private implementers, who relied on a form of clientelism - often ideologically coloured - had longstanding expertise, but insisted on their autonomy. Some actors in the system, such as care providers, did not allow themselves to be controlled without further ado. The organising principle, that the payer of provisions was also the recipient of the contribution, had been broken in the new system for workers, so that alternative forms of control had to be introduced. These were not always effective, as abuses could not always be detected and evasion of social security payments, which mainly concerned employers, continued to undermine the system. Moreover, the management of the means of control was, on the one hand, the issue of a struggle between the implementers and the parastatal institutions and, on the other hand, one of the underlying drivers of the conflict between centralization and decentralization that characterized the 1950s.

By the end of that decade, it was clear to political circles that the system needed to be reformed, but that it could above all be reformed in depth from a financial point of view, as it weighed heavily on public finances. The tenor of the social security debate was now increasingly moving in the direction of a compromise between rival trends, which was further encouraged by the de facto political reality in the 1960 s that forced opposing parties to work together in coalition governments.

\section{THE GOLDEN YEARS (1960-1975)}

The Single Law (1961) ${ }^{11}$, and its socio-economic vicissitudes, undoubtedly marked the symbolic end of a difficult transition from an obsolete economy to unprecedented industrial development. It was the beginning of a general economic recovery that continued into the 1960s. These years of economic growth resulted in increased prosperity and thus increased financial resources for social security. On the one hand, expenditure for certain risks decreased, such as unemployment, and on the other hand, the wage bill increased due to higher maximum employment rates and higher wages, so that incomes also increased. The positive balance sheet offered the possibility to extend the system both in width and depth. More population groups were integrated into the system and several benefits were increased. These were the golden years of the system. The most important milestones were the health insurance reform in August 1963 and the introduction of a social status for the self-employed in 1967. The social protection of certain categories of the population, which were not directly part of the labour market, was given a defined legal status. Social protection and social insurance thus became a right of everyone. Examples are the guaranteed income for the elderly (1968), an allowance for the disabled (1969), guaranteed family allowances (1971) and, finally, a guaranteed minimum subsistence level (1974).

This general growth of the system, which ended with the creation of an additional sector for accidents at work (1976), was also underpinned by several institutional adjustments that brought greater stability to the system, such as the division of family allowances into two separate and autonomous sub-sectors (1960: National Office for Family Allowances for Salaried Workers (ONAFTS) and National Office for Family Allowances for Self-employed Workers (ONAFTI), the creation of a National Institute for Sickness and Invalidity Insurance (INAMI) (1963), which was accompanied by a better definition of the responsibilities 
of all actors, the creation of a separate system for self-employed workers, institutionalised in the National Social Insurance Institute for the Self-employed in 1967.

During this period, the first timid steps were also taken in computerisation, both by the central level such as the NOSS, which received a new legal description in 1969, and by other parastatal institutions and individual executors (such as mutual societies, social secretariats and social security funds). Some institutions, such as the NOSS, the CNVA and the CGER, had already carried out a technical course using mechanography, especially through the Society For Mecanographie created in 1939. They switched to computer technology in the 1960s. This computerisation redefined the relationship between the parastatal institutions and the executors (such as mutual societies). The relationship was technologised and collaborative. A new technical landscape gradually emerged, with a less usurping central level (the ONSS) and better equipped ancillary institutions, both parastatal and private organisations. As a result, in this area too, a certain balance and tranquility was established. This timid computerisation was also accompanied by a desire for administrative simplification, as part of a general concept of 'modernisation', especially in employers' circles.

However, the growth and prosperity of social security was linked to economic development and therefore depended on it. That is why the economic crisis of the 1980s, triggered by the oil crisis, had such a major impact on the system. The generous system of prosperity weighed heavily on the wage burden and jeopardized the competitiveness of enterprises. The system also weighed heavily on public finances, which increasingly participated in the system as a form of redistribution. As a result, public authorities had been given greater responsibility in the system and thus greater decision-making power, in addition to employers and workers. This made the system even more receptive to the interventions of the political actor. This in itself was a step further from the basic principles of the Social Pact, which assigned a secondary role to government authorities.

\section{THE CRISIS YEARS 1975-1989}

In an initial reaction, this government adopted an attitude of incredulity and denial of the permanent nature of the crisis, as if the public debt would disappear of its own accord, according to the SP (see the statements of Budget Minister Guy Mathot on crises that resolve themselves). A later reaction came to the typical Keynesian measures that had worked in the past: public investment to alleviate the social consequences and stimulate the economy, with the example of the fight against unemployment with a thirdparty labour circuit ${ }^{12}$, or a Plan Spitaels. These measures, such as employment via a publicly subsidised "third party" labour circuit, had a limited impact and weighed heavily on public spending. By the end of the 1970s, the public deficit had changed so drastically that action had to be taken. The consolidation packages of the 1980s were the starting point; their main objective was to bring spending and revenue into line with each other. On the one hand, new revenues were discovered for social security and, on the other hand, expenditure was limited by reducing some benefits or making generic rights more specific. The austerity policy was based more on pragmatic budgetary motives than ideological ones. Concepts such as consolidation, combined with selectivity, became the new paradigm and the main thrust was to preserve public finances and not to increase the wage burden further so as not to further compromise the competitiveness of enterprises.

By the end of the 1980s, the financial system had returned to the way it was meant to be, mainly by reducing the share of social spending in the gross national product, but the new paradigm was still in force. Thanks to this policy, alternative forms of insurance could also develop, such as private insurance in health insurance and group insurance in the pension system, which implied a deterioration of the original concepts as set out in the Social Pact. The era of the great "ideological concepts", which were so present at the beginning and growth of the system, and whose controversies gave rise to a dynamic with, finally, the consensus of the 1970s, also came to an end. This ideological debate evaporated following the confrontation with the problems of the 1970s and played less of an active role in the evolution. In the meantime, the political generation involved in the creation and growth of the system had also disappeared from the political forum, with the dramatic condemnation of Edmond Leburton in 1991, the painful end of a chapter. 
At that time he was chairman of the socialist health insurance companies, but mainly famous as a political actor who formed the basis of the new health insurance (in 1963: the law Leburton). A new political generation, rather pragmatic and technical, came to power.

The ideological inspiration was replaced by the content of the knowledge centres of various universities. The inspiring socio-technician was no longer the (semi-)politician, but the scientist who looked at the social security system and formulated critical objections, such as Herman Deleeck, Roger Dillemans, Jos Viaene. Away from the spotlight, but still avant-garde, the first initiatives were taken at the university to link the use of information technology with the practice of social security. ${ }^{13}$

This scientific approach often inspired the politicians. And certainly, a rather technocratic politician like Jean-Luc Dehaene, Minister of Social Affairs from 1981 to 1988. During his term of office, a number of rather technical measures were taken, which above all changed the structure of the system. His Plan Dehaene ${ }^{14}$ provided for the creation of a Crossroads Bank for Social Security (1990) and a series of complementary technical measures that gave the system architecture the form of a vast technical network, i.e. a series of technical artefacts that communicated with each other via protocols, computer languages, gateways, etc., equipped with electronic artefacts such as directories and files including proactive controls and corrective algorithms.

\section{THE TECHNOLOGISATION OF SOCIAL SECURITY, LATE 20TH CENTURY}

The important effect of these years of consolidation was that the system had gradually moved away from the basic principles of social security. The general principle of solidarity in particular was weakened, but the principle of insurance was also weakened in some areas. Scientists referred to biased situations such as the Mattheüs effect, described by Herman Deleeck ${ }^{15}$, or the ineffectiveness of the system due to new needs and risks, as described by Bea Cantillion. ${ }^{16}$ Academic circles also, such as the Sociura ${ }^{17}$ project, proposed alternatives for technical architecture. Indeed, in the 1990s, society was confronted with a number of new structural problems that had an impact on the social security system, such as the ageing of the population or the technologisation of care, which led to an increase in expenditure.

Building more on the reorientation of the 1980 s, the policy of cost containment was continued. The achievement of the Maastricht standard for access to the European currency unit created additional pressure. On the basis of an expert report, the Prime Minister presented a preliminary draft of a new Social Pact for Social Security in 1993. It had rather symbolic value, as the concrete measures were limited.

A novelty was the Global Management, which became operational in 1995, limiting the financial autonomy of the different sectors. As a result, all revenues were centralised, deficits and reserves were pooled, and a coordinated policy could be pursued. Alternative forms of revenue were also used, so that the basic principle of the Social Pact of 1944, namely that payroll deduction was the main source of revenue, was also abandoned. Institutional adaptation was also achieved through the creation of a Social Security Management Committee, composed of employers, workers and the government, within the NOSS. The public authorities, which had been increasingly involved in the financing of social security since 1970, were thus given their legitimate responsibility for management. The fact that this was centralized in the NOSS only confirmed the historical development that this institution was the central node of the system. This concept of centralisation of the entire system has a long history ${ }^{18}$ and in fact goes back to what was formulated in 1947 by the NOSS at the time, namely the creation of a Higher Social Security Council. We see it as a turning point in the development of centralised (financial) management, which is characteristic of the "accounting" approach of the system.

But the 1990s were also characterised by the further technologisation of the social security system in two areas: data distribution and central collection. The system of central collection and subsequent distribution of funds to executors had remained virtually intact throughout the history, especially as it had adapted to technological developments. From the beginning, this system was strongly supported technologically by mechanography and, in the 1960s, by information technology (IT) under the impetus of the NOSS, which used its infra-system Society for Mécanography (in french: Société de Mécanographie pour l'Application des Lois Sociales, later Smals) for this purpose. The system had evolved from a paper 
declaration to a declaration by means of mechanically created files (initially punched cards, later magnetic tapes). This system, dormant in the early 1980s, was reactivated by the Dehaene Plan (1983), inspired by the above-mentioned academic work at the University of Leuven. As a result, the NOSS was able to resume its leadership as a technical innovator at the end of the 1980s.

The new dynamic on the technical level was the creation of the Crossroads Bank in 1990, allowing the introduction of network technology into the system. As a result, the interaction between private operators and parastatals could be organised on a technical basis. A number of accompanying measures to unify and standardise had a neutralizing effect on the execution, specifically on the distribution of insured persons' data. Institutional pluralism, which was also synonymous with compartmentalised competition, was thus further deprived of its ideological diversity.

The operation of the system was also optimised. Some electronic applications made the labour market more transparent, allowing prior checks to be carried out, administrative routines to be simplified and computerised, data to be integrated, electronic cross-checks to be carried out and the time taken to process this huge mass of contributions to be reduced. As a side-effect, a series of new partners were introduced into the social security system, who continued to support the technical system, such as service providers, social secretariats, accounting offices. Furthermore, this was the beginning (in the 2000s) of ambitious digital e-government applications in different sectors, the most striking being the significant development of the computerisation of care and the creation of the e-Health platform (2004). Many of these applications were not the product of the policy of a political or social actor, but were part of the self-generating dynamics of the system itself. A handful of socio-technicians, with extensive expertise in administrative, technical and legal fields, acted as translators of the technical possibilities.

Technical developments also made layer 4 of our institutional framework accessible (see figure 6): the citizen himself, the end user of social security, was confronted with it in a smooth way, especially in his daily use of social security. Today (2020), his accounts are largely paid to the hospital via an electronic third-party payment system, he gets reimbursement for his medicines without any administrative operations, proof of his registration in the social security system is generated electronically from the first day of employment. This proof is provided to all bodies granting benefits, without the need for them to start a new administrative collection. The mesh of the social security network has become increasingly fine, compact and therefore more efficient. Nowadays, the insured need care very little about proving or guaranteeing their rights.

FIGURE 6

SIMPLIFIED DIAGRAM OF THE SOCIAL SECURITY SYSTEM FOR WORKERS

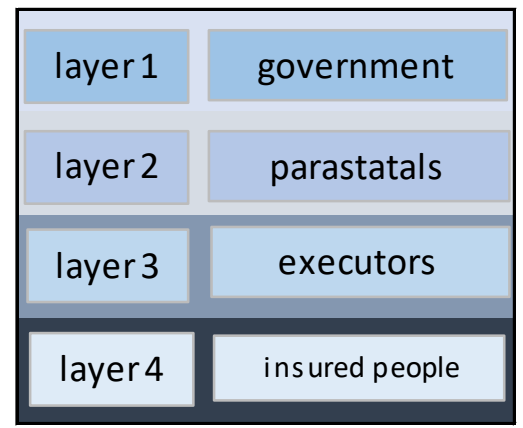

Mechanisation entered the system via layer 2 and continued through layer 3 to finally reach layer 4 at the end of the 20th century and integrate the policyholders into the large technical system that the system had become in the meantime.

This is the most recent phase of a socio-technological evolution of the social security system, in which the citizen is directly and gradually involved in the provision of data via the electronic identity card, without the intervention of third parties. This also opens the door to the direct and automatic obtaining of social 
benefits, as is already the case at present for obtaining reimbursement of medicines via Mycarenet.be or the payment of hospital bills via an automated third-party payer system. ${ }^{19}$

\section{THE TECHNICAL ANTECEDENTS OF THE FUTURE}

With this socio-technical phase, the system is moving further away from the initial principles of the Social Pact. The participation of the insured party was not yet mentioned. On the contrary, the practical implementation was entrusted to private institutions in 1944 and the insured person was the direct object that underwent and received services. This was the target group, which could be served by a range of private institutions. With technological development, there is a solution for direct citizen participation, which risks removing, more than in the past, institutional pluralism, which was one of the cornerstones of the post-war system, from its functional and institutional logic.

This technologisation is also continuing in other fields. Especially after the use of the large IT mainframe, i.e. until the 1990s, a separation remained between the operational implementation of the system and the substantive provisions of social security legislation.

Since the end of the 1990s, IT resources had been sufficiently decentralised, miniaturised and powerful to enable users to be involved, via new connection possibilities such as the Internet, in the large technical network that the system had meanwhile become. The client himself was provided with his own electronic artefact, his eID, as a successor to the information on the SIS card, with which he could connect to various networks. Networks that kept growing and getting closer to each other, until slowly but surely, they formed an invisible but all the more real network - the metaphor of the seamless web of the social constructivists. A network that today envelops the citizen, causing his or her individuality to disintegrate into a digitised virtual overvoltage.

Since the end of the 1990s, early 2000s, in parallel with this technological evolution, an adapted vision of operational functioning has developed, going further than the original technocratic, apparently neutral interpretation. This vision was adapted to the new possibilities of using technology. Just as the notion of solidarity was an element in the post-war technological framework, as well as mechanics and primary informatics, concepts such as effectiveness and efficiency became the core values of a new form of digitised social security. There was now talk of a direct G2C (government to customer) relationship that would be cheaper, transparent and user-friendly. The relationship between the citizen and the system was described in technical terms. This vision left little room for former intermediary actors. ${ }^{20}$ The technical modalities were translated into new applications and concretised in e-government applications at the beginning of the 21 st century.

This technocratic translation corresponds to what N.J. Smith describes as the basic functionality of IT in social security, i.e. that a technical social security system is only effective if it meets the individual needs of each insured person. In order to do this, the system must be able to identify the individual, detect individual needs and adapt the means accordingly. ${ }^{21}$

This was not possible in the mechanics phase or, later, in primary IT. The system had to be socially stratified and adapted to social groups such as workers, employees, large families, the disabled, etc. This was in line with the classical vision of a system covering risks and, above all, providing help on the basis of solidarity between population classes. A vision, moreover, imbued with the dependence of the Social Pact and in perfect harmony with the technical possibilities of the time.

The technical modifications with the creation of a technical network with a crossroads bank as a central artefact and later by the integration of the citizen (layer 4 in our diagram) in the technical system were innovative because the possibility was offered to realise the technical paradigm as formulated by Smith. As a result, the previous separation between the technical functioning of the system and the substantive arrangements became blurred. 


\section{FIGURE 7 \\ THE TECHNICAL-FUNCTIONAL SCHEME OF MYCARENET.BE}

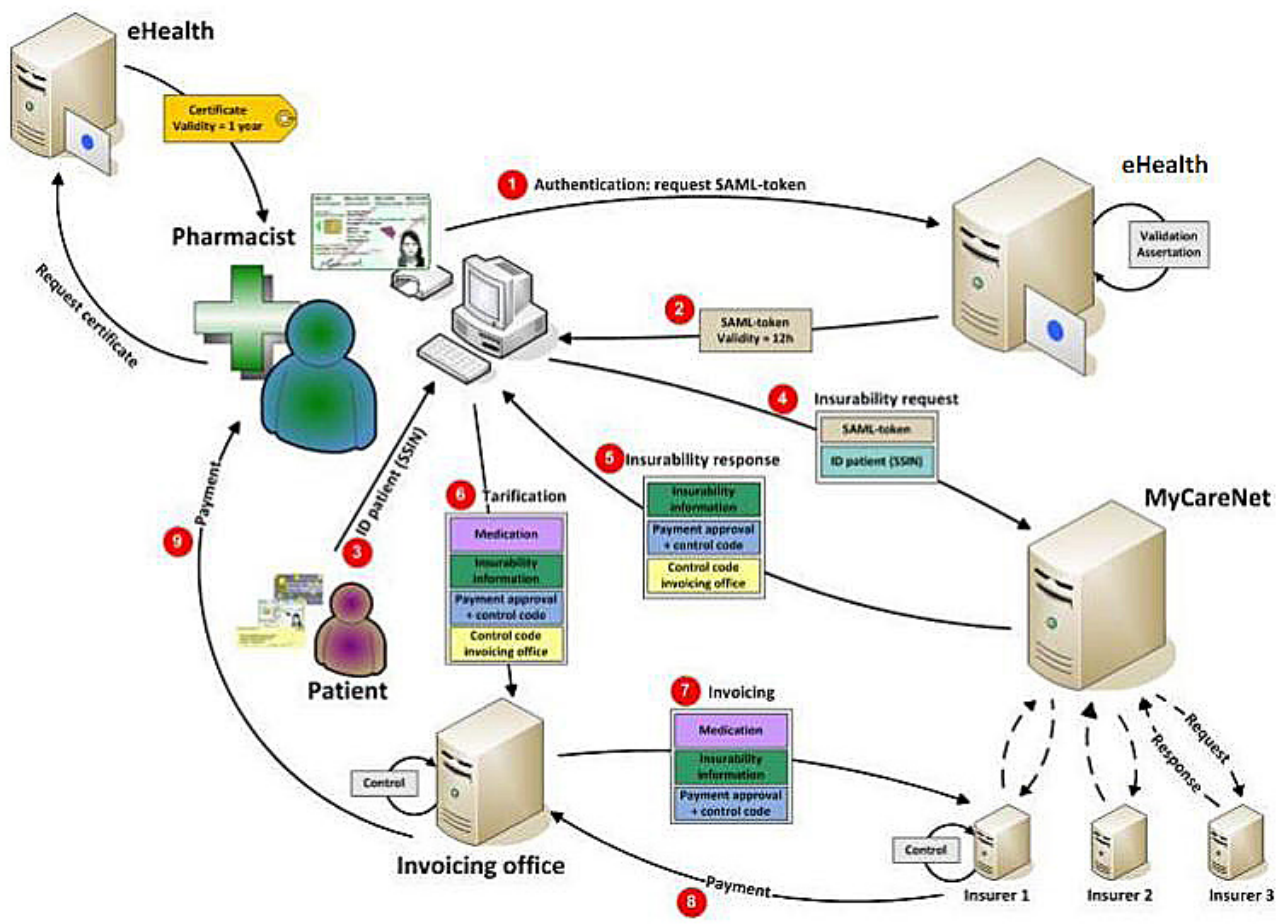

The technical-functional scheme of MyCareNet.be is an example of the technologisation of today's social security. In a non-technical language, the diagram shows the activation of IT networks when a patient visits a pharmacy. This is an example of the 'networking' of the underlying administrative processing, which is hardly comprehensible to the uninitiated. The patient himself is at no time aware that his identity is being checked, his insurability screened, etc. The patient himself is not aware that his identity is being checked, his insurability screened, etc. The patient himself is not aware that his identity is being checked. Such networks are integrated into larger constellations, making the insured person a hologram in his or her digital reality. Even though the technical artefacts may belong to ideologically coloured performers, the artefacts themselves are not linked to the ideological pillar and function on the basis of a technical language.

Source for the diagram: https://upb-avb.be/dossiers/mycarenet/, accessed 7 November 2019.

Moreover, at the end of the 20th century, a paradigm shift occurred in terms of content, as noted in particular by the sociologist Colette Bec. ${ }^{22}$ The notion of solidarity was defined in terms of equity, i.e. the distribution of the population according to their difficulties and the granting of social benefits to those most in need, but in such a way as to activate them to assume their individual responsibility as participants in a community. This is the new vision, proclaimed by the post-welfarists, which wanted to give more responsibility to the needy themselves, providing them with the means to help themselves, in complete freedom and responsibility. According to this vision, one wants to empower the individual to escape his or her situation of need, rather than letting the public authorities take full responsibility with all kinds of equipment. Conversely, this implies that other individuals who do not have special needs cannot use the facilities either. Such a system relies on the identification of the individual, the detection of his or her needs and "tailor-made" risk coverage, and, if necessary, personal monitoring and control. ${ }^{23}$ According to Bec, 'fair targeting' is the way to spend limited social security resources in a socially and economically justified way. 
Against this was the failure of the then social security system in the $1990 \mathrm{~s}$, which was based on the original concept of solidarity and broad social stratification. In this system, the need for social security support had become established and maintained, and there were few incentives to end it.

The political transposition of the new approach was the so-called "Third Way", led by several Western European governments and based on activation policy. ${ }^{24}$ In Belgium too, this found its application in government policy at the end of the 20th century, and was above all proclaimed loud and clear by the then Minister of Social Affairs and Pensions, Frank Vandenbroucke. ${ }^{25}$ A concrete example of this is the budget for care for the elderly, dependent persons, etc. So far, the activation policy continues to inspire politicians. ${ }^{26}$

We can therefore see that at this stage of social security, a convergence of developments has again taken place, just as when the Social Pact was created. On the one hand, the technical possibilities and their functional translation by socio-technicians and, on the other hand, the political conceptions (the Third Way), whose common component is the individualisation of the system. The accelerators in this process were the institutionalisation of a network (Crossroads Bank, 1990) and the technical integration of the citizen. In other words: the mentioned technical concretisation of the concept of activation policy corresponds to the description of the function given by Smith to IT in social security.

History shows that such a complementarity of actors, such as technical possibilities, concordant political conceptions and realisations, etc., has become the basis for new technological frameworks. ${ }^{27}$ But the big difference compared to earlier phases of socio-technical evolution is that the interaction between technology and system content is much greater. It seems that a turning point is approaching, as technology offers the possibility to develop an alternative insurance system based on "fair targeting". The inevitable convergence between, on the one hand, the technical possibilities and, on the other hand, the political will to use them, also seems to be taking place in this area. The impact of technology on the content of the system has become direct.

Is this what Matthias Somers, scientific collaborator at the Minerva think tank, meant in 2019 by "the erosion of social security [which] threatens to further fragment society. An infernal machine is set in motion, tearing at the fabric of society - and we find ourselves alone?"28

Or should we consider the notion of "solidarity" as a historical concept, which is obsolete and which was (and still is) rooted in a form of dependency that determines the reflection on structure and functioning from the past, but which can today be realised differently in a new socio-technical context, notably thanks to new technical possibilities?

This technological development does not, of course, provide ready-made solutions to other major social problems facing social security at the beginning of the 21 st century. Cantillon cites ageing, climate change and the third industrial revolution as challenges. ${ }^{29}$ In addition, the technologisation of social security is causing related problems, such as the protection of privacy, control of data integration and use, cybercrime attacks, etc. ${ }^{30}$ Late developments will certainly occur, which will hamper evolution, such as the maintenance of historical concepts, survival strategies of obsolete procedures and organisations.

But the new generation of socio-technicians certainly has an answer to the question of how to manage resources rationally, possibly with the help of meta-information that the technical system can provide, or algorithms that help to achieve fair targeting.

\section{CONCLUSION}

The social security system, based on the Social Pact, was in itself a typically Belgian product: the institutional tinkering was done with typically Belgian means and concepts. The inspiration coming from the executor was limited.

Initially, the system was not perfect and required constant adaptation. But this also proved to be the strength of the system: it had sufficient adaptability to occupy a central function in the welfare state until now. Several characteristics can be mentioned which had a favourable impact on this adaptability, such as the choice of a central perception which brought financial stability, the parity-based management which allowed the system to acquire autonomy and develop autodynamism, the early mechanisation of the central system which allowed the system to access computerisation at an early stage, the contribution of socio- 
technicians who were able to give a basic orientation, the presence of parastatal institutions which structured the complex landscape of institutional pluralism.

The most striking feature is the fact that the social security system was from the outset a complex sociotechnical construction carried by an entire community. The complexity, the participation of many different actors, the technicality, the interactions between all these components, even controversies, created a dynamic that enabled it to renew itself constantly.

However, we can also state that the current social security system still has a number of antecedents dating back to the Social Pact, but has also evolved considerably from the original starting principles. The current technological system is no longer based on institutional pluralism; it can give another definition to the notion of solidarity; it gives the citizen direct access to services; it is more transparent, but it is also more than ever a "black box"; it is easy to integrate with other technical networks.

The current system has all the characteristics of a large socio-technical system whose characteristics are politicised and whose operating principles are technologised.

It is precisely for this reason that it resembles less and less the system created in 1944 with which private organisations, and therefore their political allies, had identified themselves. This obviously remains a memory, but as the NOSS says: it has become a "modern" social security system.

In this context, there is therefore less need to go back to a past with which one could identify, but rather to look to the future. This reminds us of Paul Klee's emblematic painting Angelus Novus, the angel who sees history as a great mess, but who, out of the corner of his eye, looks to the future, driven by the storm of the past. The storm that is progress.

FIGURE 8

ANGELUS NOVUS BY PAUL KLEE

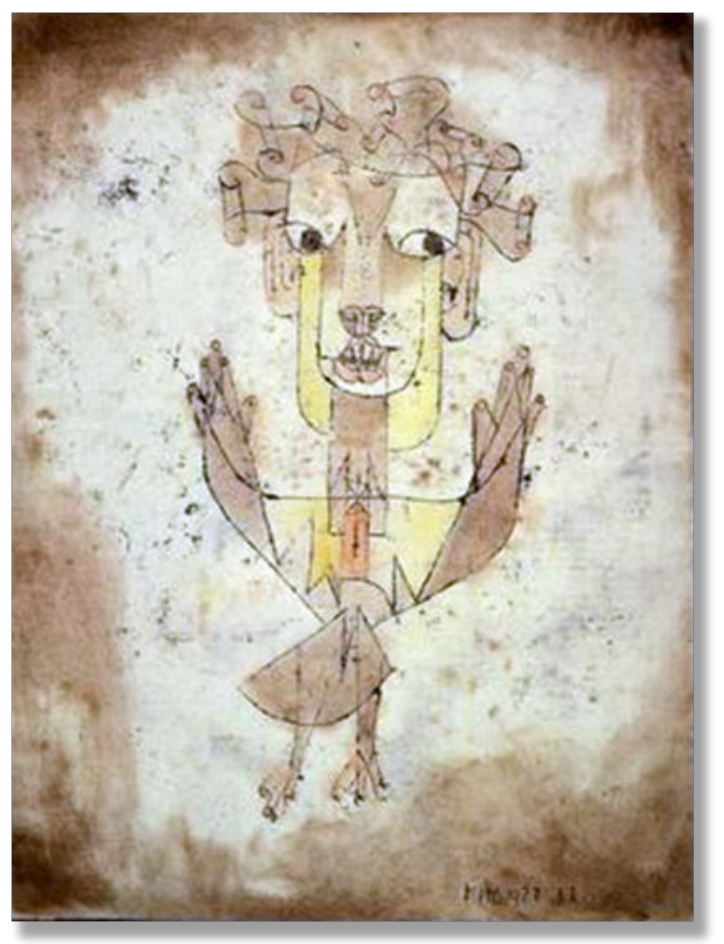

Paul Klee's Angelus Novus looks at the future from the corner of the eye, propelled by the storm of the past. The storm that is progress. Was this the attitude of the social scientists in 2019, when they looked at the Social Pact of 1944? 


\section{ACKNOWLEDGEMENT}

Translated \& edited by American Publishing Services (https://americanpublishingservices.com/).

\section{ENDNOTES}

1. This overview is based on: Chlepner, Ben Serge, Cent ans d'histoire sociale en Belgique. Postface de René Evalenko. (Bruxelles, Institut de sociologie Solvay, 1956/1972) ; Delhuvenne, Michel, 'De geschiedkundige ontwikkeling van de sociale zekerheid in België (1945-1980)', in Frank, Max, ed., Geschiedenis van de openbare financiën in België. 4: de period 1950-1980, Bruxelles, Bruylant, pp. 635-693, 1988; Deleeck, Herman, De architectuur van de welvaartsstaat opnieuw bekeken, Leuven, Acco, 2001; Arcq, Etienne and Blaise, Pierre, 'Politieke Geschiedenis van de Sociale Zekerheid in België', Belgisch Tijdschrift voor Sociale Zekerheid, 1998, nr. 3, pp. 489-744; Vanthemsche, Guy, De beginjaren van de sociale zekerheid in België 1944-1963, Brussels, 1995; Vandeputte, Robert, Sociale geschiedenis van België. 1944-1985, Tielt, Lannoo, 1987; Van Lerberge, Raphaël, Het technische gewicht. Socio-technische transformaties in de Belgische Sociale Zekerheid, doctoral thesis, VUBpress, 2020.

2. Luyten, Dirk, 75 jaar geleden: de geboorte van onze sociale zekerheid, consulted 8 jan. 2020 on : https://www.vrt.be/vrtnws/nl/drafts/jan-ouvry/75-jaar-geleden-de-geboorte-van-onze-sociale-zekerheid/.

3. Vleminck, Koen, 'De (r)evolutie van de sociale zekerheid: 1944 tot nu', in: SOMERS, Matthias (ed.), Fundamenten. Sociale zekerheid in onzekere tijden, Minerva progressieve denktank. Consulted on www.denktankminerva.be., p. $22-63$.

4. Cantillon, Bea, 75 jaar sociale zekerheid. Compagnon de route in tijden van verandering, published on http://www.centrumvoorsociaalbeleid.be/index.php?q=biblio/author/32 (consulted 15 dec. 2019).

5. https://www.75jaarrsz.be/fr/

6. Jacques, Catherine, Marissal, Claudine, Puissant, Jean et Gubin, Eliane, Les débuts de l'Office national de sécurité sociale, publication non éditée, Vrije Universiteit Brussel, p. 10, 1995

7. Vanthemsche, G., De beginjaren van de sociale zekerheid in België 1944-1963, o.c., p. 31

8. Lanzara, Giovan Francesco, Self-destructive processes in institution building and some modest countervailing mechanism, European Journal of Political Research, 33, pp. 1-39, 1998.

9. It almost became a semantic discussion of whether L.-E. Troclet was or was not a statist. A significant discussion, because Troclet can certainly be considered institutionally as the architect-executor of the postwar system. His numerous writings: Troclet, Léon-Eli, Problèmes belges de la sécurité sociale, tome 1, Bruxelles, Impr. D. Van Keerberghen \& Fils, 1949, provide no clarity on this subject. He associates with it an amalgam of contradictory ideas. He links centralization to deconcentration, speaks of autonomy and joint management, but sees them subordinate to ministerial competence as a requirement of "democracy". It opposes execution by ministerial services, while giving them an important monitoring role. He plunges these visions into thinly veiled admiration for the Beveridge plan. From our contemporary perspective, we can only describe this as confusing. For clarity, it's best to focus on his accomplishments as a minister, which were heavily coloured personally. We consider the National Office for the Coordination of Family Allowances, created in 1947, as a model of its conceptions. It was an autonomous institution, not linked to a pillar, managed jointly, which worked under the direct supervision of the Minister, with a significant contribution from a group of socio-technicians.

10. Van Lerberge, Raphaël, Het technische gewicht. Socio-technische transformaties in de Belgische Sociale Zekerheid o.c., p. 187.

11. The Single Law (La Loi Unique or de Eenheidswet) is officially called the law of 14 February 1961 on economic expansion, social progress and financial recovery.

12. The third party in that case was the government, which itself developed employment initiatives, for example in the healthcare sector

13. Robben, Frank, La genèse politique de la Banque-Carrefour de la Sécurité Sociale, published on: https://www.frankrobben.be/wp-content/uploads/2018/08/1990-033.pdf.

14. Propositions du Ministre des Affaires sociales relatives à la réforme de la sécurité sociale (Plan Dehaene), Bruxelles, s.l., pp. 233-236, 1983.

15. Deleeck, H., Huybrechs, J., Cantillon, B., Het Matteüseffect: de ongelijke verdeling van de sociale overheidsuitgaven in België, Antwerpen, Kluwer, 1983.

16. Cantillon, Bea (red.), De welvaartsstaat in de kering, Kapellen, édition Pelckmans, 1999. 
17. Dillemans, Roger (éd.), Bouwstenen voor een nieuwe sociale zekerheid. Sociura-project, Leuven, Universitaire Pers Leuven, 1993.

18. Deffet, Michel, 'Historisch overzicht', Belgisch Tijdschrift voor Sociale Zekerheid, 1997, nr. 2, pp. 287-327 and Arcq, Etienne, 'De doeleinden', Belgisch Tijdschrift voor Sociale Zekerheid, 1997, nr. 2, pp. 329-364. According to the latter author, it is a product of long and slow development, in which " le pragmatisme est un moyen éprouvé pour éliminer le résultat de doctrines exclusives » (o.c., p. 357) (pragmatism is a proven means of eliminating the result of exclusive doctrines). We did not have the possibility to also analyze the technical foundations of this Global Management and we wonder to what extent the production of metainformation, and therefore the availability of specific technical systems, has contributed to the concept of Global Management.

19. The two cases are developed and discussed in Van Lerberge, Raphaël, Het technische gewicht. Sociotechnische transformaties in de Belgische Sociale Zekerheid, o.c., pp. 500-502.

20. Robben, Frank and Deprest, Jan, E-Government: the approach of the Belgian federal administration, Bruxelles, p. 3, 2003

21. Smith, Norman Jones, Social Welfare and computers. A general outline, Melbourne, Longman Cheshire, p. $6,1985$.

22. Bec, Colette, La Sécurité Sociale. Une institution de la démocratie, Paris, Gallimard, p. 224 et suivantes, 2014. In this regard, she refers to the influence of the theory of justice of the philosopher John Rawls.

23. Franssens, Abraham, Etat social actif : une nouvelle grammaire des risques sociaux, in Cartuyvels, Yves (dir.), Les ambivalences du risque : regards croisés en sciences sociales, Bruxelles, Publication des Facultés Universitaires Saint Louis, p. 123, 2008, consulted 16 Decembre 2019 on http:/hdl.handle.net/2078/184697

24. Holemans, Dirk, La troisième voie: die neue Mitte / Mythe ?, La revue nouvelle, April 2000. Among the political translators of the concept, let us quote Gerhard Schroeder and Tony Blair. In Belgium: Frank Vandenbroucke, but also Guy Verhofstadt were favorable. A good analysis also in: Smeets, Sibylle, Nouveaux uniformes et Etat social actif : vers une recomposition du champ de la sécurité en Belgique, thèse de doctorat, ULB, pp. 335-486, 2006.

25. Franssens, Abraham, Etat social actif: une nouvelle grammaire des risques sociaux, o.c., p. 119.

26. During the celebration of December 20, 2019, which was held in the House of Representatives on the occasion of the 75 years of social security, Minister of Social Affairs Maggie De Block made a strong plea for solidarity and 'increased activity rate as a parameter of system success.

27. Van Lerberge, Raphaël, Het technische gewicht. Socio-technische transformaties in de Belgische sociale zekerheid. o.c.

28. Somers, Matthias (éd.), Fundamenten. Sociale zekerheid in onzekere tijden, Minerva progressieve denktank, p. 19, 2019. In the study by Bec, Colette, La Sécurité Sociale. Une institution de la démocratie, o.c., p. 226 : 'L'individu est isolé de tout social'.

29. Cantillon, Bea, 75 jaar sociale zekerheid. Compagnon de route in tijden van verandering, o.c., p. 4.

30. The recent (early 2020) COVID 19 crisis shows how quickly standards can change in this area, thanks to or through technologies such as monitoring individual body temperature in an organized context not only in hospitals but also in public places (like the metro, see China); or the recording and systematic detection of individuals infected by corona with an indication on an "application", to be viewed on a smartphone, etc., even including a specific "corona cybercrime". 